\title{
RENAL FUNCTION IN PRIMARY ALDOSTERONISM ${ }^{1}$
}

\author{
By HARRIET P. DUSTAN, A. C. CORCORAN, AND IRVINE H. PAGE \\ (From the Research Division of The Cleveland Clinic Foundation and The Frank E. Bunts \\ Educational Institute, Cleveland, O.)
}

(Submitted for publication June 11, 1956; accepted August 9, 1956)

Primary aldosteronism is characterized by weakness-a sequel to potassium loss; hypertensionattributed to sodium retention; thirst and polyuria; and excretion of dilute, alkaline urine (1). These defects imply significant changes in renal function.

The purpose of this report is to describe preand postoperative observations of renal function in three patients suffering from aldosterone-secreting adrenal cortical tumors.

The data indicate that excess urinary potassium excretion is attributable to aldosteronism as such, and may bear on the basic cellular mechanism of action of aldosterone. The polyuria and excretion of dilute urine are recognized sequelae of potassium deficiency and probably not directly due to hormonal action. It also seems likely that renal tubular fluid as delivered from some proximal site to more distal tubules may be hypotonic rather than isotonic. The data suggest that aldosterone has profound effects on the maintenance of renal blood flow and glomerular filtration rates. From the clinical aspect, the diagnosis of aldosteronism should be strongly suspected in patients with hypertension of unknown origin who, in the presence of adequate renal excretory function, excrete alkaline urine and show loss of urinary concentrating power.

\section{METHODS AND PROCEDURES}

The three patients studied suffered from primary aldosteronism which was cured by resection of small adrenal cortical adenomata. Detailed diagnostic data together with evidences of impaired glucose tolerance are reported elsewhere (2). All three had had hypertension for years, all showed hypokalemia with hypochloremic alkalosis, impairment of urinary concentrating power and persistently alkaline urine. Preoperatively, the aldosterone content of the urine was increased in each.

Renal functions were studied pre- and postoperatively. Renal plasma flow and glomerular filtration rate were measured from the plasma clearances of para-aminohip-

1 Presented at the 28th Annual Meeting of the Central Society for Clinical Research, Chicago, I1l., Nov. 5th, 1955. purate (PAH) and mannitol. Total renal vascular resistance was calculated by the formula of Gomez (3). The functions of water conservation and electrolyte excretion were observed simultaneously. Water conservation was determined from the differences $\left(T^{e} \mathbf{H}_{20}\right)$ between urine flow (V) and osmolal clearance ( $\mathrm{C}_{0 . \mathrm{m}}$ ) (4) during osmotic diuresis in hydropenia (water deprivation for 16 or 24 hours and/or infusion of Pitressin(8). The priming solution contained $260 \mathrm{mOsm}$. of mannitol and $0.6 \mathrm{gm}$. of $\mathrm{PAH}$; the sustaining infusion supplied about $3 \mathrm{mOsm}$. of mannitol and $15 \mathrm{mg}$. per PAH per minute. Urine formed during the first 20 minutes was discarded; it was then collected from an indwelling urethral catheter at 3 to 6 successive intervals of about $10 \mathrm{~min}$ utes; blood was sampled prior to giving the priming solution and at intervals of about 20 minutes. Urine and plasma were analyzed for PAH and mannitol (5), chloride (6), sodium, potassium, and osmolality. Sodium and potassium determinations were done with a Baird flame photometer using lithium as the internal standard. Osmolality was determined cryoscopically, using a Fiske Osmometer.

Urinary concentrating power was measured from the nonprotein specific gravity of urine collected during the last 12 hours of a 24-hour period of fluid deprivation (5). The specimen was also used for determinations of proteinuria, $\mathrm{pH}$ and the urinary sediment count.

\section{RESULTS}

\section{Renal hemodynamics (Table I)}

(a) Preoperative. Plasma clearances of $\mathrm{PAH}$ $\left(C_{P A B}\right)$ were somewhat depressed, but plasma clearances of mannitol $\left(C_{M}\right)$ were within the range of normal; filtration fraction was increased in patients 1 and 3. Blood pressure was elevated in all. Renal vascular resistance (R) was increased in patients 1 and 2; this function was not calculated in patient 3. In this last patient a low $\mathrm{C}_{\mathrm{PAB}}$ and very high filtration fraction indicated that renal extraction of PAH might be defective, so that $\mathrm{C}_{\mathrm{PAB}}$ was not considered equivalent to renal plasma flow.

(b) Postoperative. Two weeks to two months after operation, $\mathrm{C}_{\mathbf{P A B}}$ was further decreased in all, with associated decreases in $C_{\mathbf{M}}$ and decreases in filtration fraction in patients 1 and 3, Mean 
TABLE I

Hemodynamic data preoperatively and postoperatively *

\begin{tabular}{|c|c|c|c|c|c|c|}
\hline \multirow[b]{2}{*}{ Patient } & \multirow{2}{*}{$\begin{array}{l}\text { Time of } \\
\text { study }\end{array}$} & $\mathrm{C}_{P A B}$ & $\mathrm{C}_{\mathbf{M}}$ & \multirow[b]{2}{*}{ F.F. } & \multirow{2}{*}{$\underset{m m . H g}{P m}$} & \multirow{2}{*}{$\begin{array}{r}\mathbf{R} \times 10^{9} \\
\text { dymes per } \\
\text { sec. per } \\
c^{-6}\end{array}$} \\
\hline & & \multicolumn{2}{|c|}{ ml. per min. } & & & \\
\hline \multirow[t]{2}{*}{1} & \multirow{2}{*}{$\begin{array}{l}\text { Preop. } \\
\text { Postop. } \\
2 \text { mo. } \\
6 \frac{1}{2} \text { mo. }\end{array}$} & 412 & 109 & 0.29 & 134 & 14.67 \\
\hline & & $\begin{array}{l}275 \\
531\end{array}$ & $\begin{array}{l}41 \\
80\end{array}$ & $\begin{array}{l}0.16 \\
0.17\end{array}$ & $\begin{array}{l}102 \\
102\end{array}$ & $\begin{array}{r}19.8 \\
7.8\end{array}$ \\
\hline \multirow[t]{2}{*}{2} & \multirow{2}{*}{$\begin{array}{l}\text { Preop. } \\
\text { Postop. } \\
1 \text { mo. } \\
4 \text { mo. }\end{array}$} & 443 & 84 & 0.21 & 166 & 16.83 \\
\hline & & $\begin{array}{l}367 \\
343\end{array}$ & $\begin{array}{l}71 \\
91\end{array}$ & $\begin{array}{l}0.21 \\
0.30\end{array}$ & $\begin{array}{l}157 \\
165\end{array}$ & $\begin{array}{l}16.49 \\
20.3\end{array}$ \\
\hline \multirow[t]{2}{*}{3} & \multirow{2}{*}{$\begin{array}{l}\text { Preop. } \\
\text { Postop. } \\
2 \text { wk. } \\
3 \text { mo. }\end{array}$} & 262 & 113 & 0.48 & 137 & \\
\hline & & $\begin{array}{l}173 \\
218\end{array}$ & $\begin{array}{l}37 \\
51\end{array}$ & $\begin{array}{l}0.24 \\
0.27\end{array}$ & $\begin{array}{l}103 \\
123\end{array}$ & $\begin{array}{l}24.0 \\
21.9\end{array}$ \\
\hline
\end{tabular}

* Patient numbers as in text. Plasma clearances $(C)$ of p-aminohippurate (PAH) at low plasma concentrations, and of mannitol (M) in ml. per minute per 1.73 sq. $\mathrm{m}$. of body surface, the data being averages of serial periods of urinary collection. Filtration fraction (F.F.), mean of averages of systolic and diastolic arterial pressures (Pm), and renal vascular resistance (R).

blood pressure $(\mathrm{Pm})$ had returned to normal in patients 1 and 3 and remained high in patient 2 , whereas $R$ was abnormally high in all. Three to 6 months after operation, $\mathrm{C}_{\mathrm{PAB}}$ had returned to a normal level in patient 1 , was unchanged in patient 2 , and was slightly increased over the last determination in patient $2 . \mathrm{C}_{\mathrm{M}}$ had returned to normal levels in patients 1 and 2, and was somewhat increased over the previous determination in patient 3 ; blood pressure was at normal levels only in patient 1 . $\mathrm{R}$ was greatly decreased since the last observation in patient 1 , slightly decreased in patient 3 , and somewhat increased in patient 2 .

\section{Water conservation (Table II)}

(a) Preoperative. Although excretory functions in terms of $C_{\mathbf{P A H}}$ and $\mathrm{C}_{\mathbf{M}}$ were not greatly depressed, maximal urinary nonprotein specific gravities were disproportionately low. During osmotic diuresis, either after water deprivation, during Pitressin infusion, or in the presence of both, the urine/plasma osmolality ratio $\left(\mathrm{U} / \mathrm{P}_{\mathrm{Osm}}\right)$ approximated unity, so that water conservation function $\left(\mathrm{T}^{\mathrm{c}} \mathrm{H}_{2} \mathrm{O}\right)$ could be calculated only in patient 2 ; there was net excretion (clearance) of free water $\left(\mathrm{C}_{\mathrm{H}_{2} \mathrm{O}}\right)$ at rates of 0.12 and $0.71 \mathrm{ml}$. per minute in patients 1 and 3, respectively.

(b) Postoperative. Maximum urinary specific gravity was not increased in the first observations in patients 1 and 2, but had increased slightly in patient 3 . In the second set of observations, there was still no change in patient 1 , a slight increase in patient 2 , and, as compared with the preopera-

TABLE II

Water conservation *

\begin{tabular}{|c|c|c|c|c|c|c|c|c|c|}
\hline \multirow[b]{2}{*}{$\stackrel{1}{\text { Patient }}$} & \multirow[b]{2}{*}{$\underset{\text { Time of }}{2}$} & \multirow[b]{2}{*}{$\begin{array}{c}3 \\
\text { Max. urine } \\
\text { sp. gr. } \\
\text { (Addis) }\end{array}$} & \multicolumn{7}{|c|}{ During osmotic diuresis } \\
\hline & & & $\begin{array}{c}4 \\
\mathrm{Com}\end{array}$ & $\begin{array}{l}5 \\
\mathrm{v}\end{array}$ & $\begin{array}{c}6 \\
\mathrm{~T}{ }^{\circ} \mathrm{H}_{2} \mathrm{O} \\
\text { per min. }\end{array}$ & $\begin{array}{c}7 \\
\mathrm{C}_{\mathrm{H}_{2} \mathrm{O}}\end{array}$ & $\begin{array}{c}8 \\
\frac{\mathrm{T}^{\circ} \mathrm{H}_{2} \mathrm{O}}{\mathrm{C}_{M}} \times 100\end{array}$ & U/P Osm & $\stackrel{10}{\text { Stimulus }}$ \\
\hline \multirow[t]{2}{*}{1} & Preop. & 1.016 & 13.11 & 13.23 & & .12 & & .99 & $\begin{array}{l}\text { Hydropenia } \\
\text { Pitressin }\left({ }^{2}\right.\end{array}$ \\
\hline & $\begin{array}{l}\text { Postop. } \\
2 \mathrm{mo} . \\
6 \frac{1}{2} \mathrm{mo} .\end{array}$ & $\begin{array}{l}1.015 \\
1.017\end{array}$ & $\begin{array}{l}3.96 \\
5.45\end{array}$ & $\begin{array}{l}2.44 \\
2.91\end{array}$ & $\begin{array}{l}1.52 \\
2.54\end{array}$ & & $\begin{array}{l}3.77 \\
3.17\end{array}$ & $\begin{array}{l}1.62 \\
1.88\end{array}$ & $\begin{array}{l}\text { Hydropenia } \\
\text { Pitressin (8) }\end{array}$ \\
\hline \multirow[t]{2}{*}{2} & Preop. & 1.013 & 13.82 & 13.23 & .59 & & & 1.04 & Pitressin ( 1 \\
\hline & $1 \mathrm{mo}$. & $\begin{array}{l}1.014 \\
1.017\end{array}$ & $\begin{array}{l}11.90 \\
12.34\end{array}$ & $\begin{array}{l}7.80 \\
8.02\end{array}$ & $\begin{array}{l}4.10 \\
4.32\end{array}$ & & $\begin{array}{l}5.80 \\
4.76\end{array}$ & $\begin{array}{l}1.52 \\
1.54\end{array}$ & $\begin{array}{l}\text { Hydropenia } \\
\text { Hydropenia }\end{array}$ \\
\hline \multirow[t]{2}{*}{3} & Preop. & 1.011 & 16.29 & 17.00 & & .71 & & .96 & Pitressin $®$ \\
\hline & $\begin{array}{l}2 \text { wk. } \\
3 \text { mo. }\end{array}$ & $\begin{array}{l}1.016 \\
1.017\end{array}$ & $\begin{array}{r}6.40 \\
10.57\end{array}$ & $\begin{array}{l}4.82 \\
8.24\end{array}$ & $\begin{array}{l}1.58 \\
2.33\end{array}$ & & $\begin{array}{l}4.20 \\
4.67\end{array}$ & $\begin{array}{l}1.33 \\
1.28\end{array}$ & $\begin{array}{l}\text { Pitressin }(3) \\
\text { Hydropenia }\end{array}$ \\
\hline
\end{tabular}

* Maximum urinary specific gravities during Addis concentration tests (column 3). Subsequent columns are data obtained during clearance measurements as in Table I. Osmolal clearance (Coum), urinary volume (V), maximum rate of water reabsorption in urinary concentration $\left(\mathrm{T}^{\circ} \mathrm{C}_{2} \mathrm{O}\right)$, and rate of positive free water clearance $\left(\mathrm{C}_{\mathrm{H}_{2} \mathrm{O}}\right)$, all in $\mathrm{ml}$. per minute per $1.73 \mathrm{sq}$. $\mathrm{m}$. of body surface. $\mathrm{T}_{\mathrm{H}_{2} \mathrm{O}}$ also is expressed in units per $100 \mathrm{ml}$. of plasma mannitol clearance. Column 9 lists the values of the ratio of urinary/plasma osmolality, and column 10 indicates the stimulus (hydropenia or Pitressin (8), each alone or combined) to water conservation in the tests. 
tive test, a large increase in patient 3 . During osmotic diuresis, the ratio $\mathrm{U} / \mathrm{P}_{\mathrm{Osm}}$ was greater than unity, so that the water conservation function $\mathrm{T}^{\mathrm{c}}{ }_{\mathrm{H}_{2} \mathrm{O}}$ was distinctly positive in all three patients. At the first observation, $\mathrm{C}_{\mathrm{Osm}}$ was depressed in patients 1 and 3 by decreased glomerular filtration rates; calculations of $\mathrm{T}^{\mathrm{c}}{ }_{\mathrm{H}_{2} \mathrm{O}}$ in relation to filtration rate $\left(\mathrm{T}^{\mathrm{c}} \mathrm{H}_{2} \mathrm{O} / \mathrm{C}_{\mathrm{M}}\right)$ indicated normal values with little change in the subsequent observations, although $\mathrm{C}_{M}$ increased in patients 1 and 3.

\section{Plasma electrolytes and electrolyte excretion (Table III)}

(a) Preoperative. Serum sodium was within the normal range; serum potassium was low and $\mathrm{CO}_{2}$ combining power increased. In spite of the hypokalemic, hypochloremic alkalosis, urinary $\mathrm{pH}$ was persistently 7 or more, even during concentration tests, in which the urine is usually acid.

During osmotic diuresis, the percentage of filtered sodium which was reabsorbed varied from 95.08 (patient 1) to 91.6 (patient 3) ; potassium excretion $\left(U_{K} V\right)$ was greatly augmented, with the ratio $C_{K} / C_{M}$ ranging from 0.5 to 0.8 . Patient 3 was given acetazoleamide (Diamox $\left.{ }^{(}\right)$intravenously, with resultant further decrease in sodium reabsorption and increase in the ratio $\mathrm{C}_{\mathbf{K}} / \mathrm{C}_{\mathbf{M}}$ from 0.79 to 1.32 .
TABLE IIIA

Urine pH and plasma electrolytes

\begin{tabular}{|c|c|c|c|c|c|c|}
\hline \multirow[b]{2}{*}{ Patient } & \multirow{2}{*}{$\begin{array}{l}\text { Time of } \\
\text { study }\end{array}$} & \multirow{2}{*}{$\underset{\mathbf{p H}}{\text { Urine }}$} & \multicolumn{4}{|c|}{$\begin{array}{l}\text { Plasma electrolytes } \\
(m E q . / L .)\end{array}$} \\
\hline & & & $\mathrm{Na}$ & $\mathbf{K}$ & $\mathrm{Cl}$ & $\mathrm{CO}_{2}$ \\
\hline \multirow[t]{2}{*}{1} & \multirow{2}{*}{$\begin{array}{l}\text { Preop. } \\
\text { Postop. } \\
2 \text { mo. } \\
6 \frac{1}{2} \text { mo. }\end{array}$} & 7.0 & 145 & 2.8 & 87.5 & 35.8 \\
\hline & & $\begin{array}{l}5.5 \\
5.5\end{array}$ & $\begin{array}{l}145 \\
145\end{array}$ & $\begin{array}{l}5.6 \\
5.3\end{array}$ & $\begin{array}{l}104 \\
104\end{array}$ & $\begin{array}{l}17.6 \\
22.3\end{array}$ \\
\hline \multirow[t]{2}{*}{2} & \multirow{2}{*}{$\begin{array}{l}\text { Preop. } \\
\text { Postop. } \\
1 \text { mo. } \\
5 \text { mo. }\end{array}$} & 7.5 & 141 & 2.4 & 93 & 32.0 \\
\hline & & $\begin{array}{l}5.5 \\
5.5\end{array}$ & $\begin{array}{l}135 \\
148\end{array}$ & $\begin{array}{l}4.3 \\
5.0\end{array}$ & $\begin{array}{l}101 \\
113\end{array}$ & $\begin{array}{l}21.4 \\
19.7\end{array}$ \\
\hline \multirow[t]{2}{*}{3} & \multirow{2}{*}{$\begin{array}{l}\text { Preop. } \\
\text { Postop. } \\
2 \text { wk. } \\
3 \text { mo. }\end{array}$} & 7.5 & 143 & 1.8 & 90.3 & 31.2 \\
\hline & & $\begin{array}{l}\dot{6} .5 \\
5.5\end{array}$ & $\begin{array}{l}147 \\
145\end{array}$ & $\begin{array}{l}5.3 \\
4.7\end{array}$ & $\begin{array}{r}101.5 \\
95.9\end{array}$ & $\begin{array}{l}20.1 \\
23.1\end{array}$ \\
\hline
\end{tabular}

(b) Postoperative. In each patient, hypochloremic alkalosis was replaced by acidosis, and hypokalemia by normal or slightly increased serum potassium concentrations. These changes were mild and transient in patient 3 , but persistent in patients 1 and 2 at $61 / 2$ and 4 months, respectively, after operation. The urine became acid shortly after operation.

At the first observation during osmotic diuresis, the percentage of filtered sodium which was reabsorbed was decreased in patient 2 and increased in patients 1 and 3 ; the filtered sodium load ( $\mathrm{L}_{\mathrm{Na}}$, viz., $\mathrm{P}_{\mathrm{Na}} \times \mathrm{GFR}$ ) was decreased in all.

TABLE IIIB

Electrolyte excretion *

\begin{tabular}{|c|c|c|c|c|c|c|c|}
\hline \multirow{3}{*}{$\frac{\text { Patient }}{1}$} & \multirow{3}{*}{$\begin{array}{c}\begin{array}{c}\text { Time of } \\
\text { study }\end{array} \\
\text { Preop. } \\
\text { Postop. } \\
2 \text { mo. } \\
6 \frac{1}{2} \text { mo. }\end{array}$} & \multicolumn{2}{|c|}{$\underset{m E g_{0} / \min .}{\mathrm{U}_{\mathrm{NV}} \mathrm{V}}$} & \multirow{2}{*}{$\begin{array}{c}\begin{array}{c}\text { Per cent } \\
\text { Na reab. }\end{array} \\
95.08\end{array}$} & \multicolumn{2}{|c|}{$\underset{m E q . / \min .}{\mathrm{U}_{\mathrm{K}} \mathrm{VV}}$} & \multirow{2}{*}{$\frac{C_{k} / C_{k}}{.51}$} \\
\hline & & 14.8 & .727 & & .334 & .146 & \\
\hline & & $\begin{array}{r}5.65 \\
12.48\end{array}$ & $\begin{array}{l}.183 \\
.241\end{array}$ & $\begin{array}{l}96.7 \\
98.06\end{array}$ & $\begin{array}{l}.260 \\
.436\end{array}$ & $\begin{array}{l}.053 \\
.043\end{array}$ & $\begin{array}{l}.23 \\
.11\end{array}$ \\
\hline \multirow[t]{2}{*}{2} & $\begin{array}{l}\text { Preop. } \\
\text { Postop. }\end{array}$ & 13.2 & .939 & 92.8 & .296 & .213 & .80 \\
\hline & $1 \mathrm{mo}$. & $\begin{array}{c}9.6 \\
14.53\end{array}$ & $\begin{array}{l}.828 \\
.965\end{array}$ & $\begin{array}{l}91.37 \\
93.38\end{array}$ & $\begin{array}{l}.333 \\
.416\end{array}$ & $\begin{array}{l}.125 \\
.114\end{array}$ & $\begin{array}{l}.37 \\
.32\end{array}$ \\
\hline \multirow[t]{3}{*}{3} & Preop. & & & & & & \\
\hline & $\begin{array}{c}\text { Control } \\
\text { Diamox } \$\end{array}$ & $\begin{array}{l}16.1 \\
11.8\end{array}$ & $\begin{array}{l}1.342 \\
1.898\end{array}$ & $\begin{array}{l}91.60 \\
83.07\end{array}$ & $\begin{array}{l}.304 \\
.192\end{array}$ & $\begin{array}{l}.231 \\
.252\end{array}$ & $\begin{array}{r}.78 \\
1.32\end{array}$ \\
\hline & $\begin{array}{l}\text { Postop. } \\
2 \text { wk. } \\
3 \text { mo. }\end{array}$ & $\begin{array}{l}5.4 \\
7.7\end{array}$ & $\begin{array}{l}.353 \\
.827\end{array}$ & $\begin{array}{l}93.46 \\
88.76\end{array}$ & $\begin{array}{l}.174 \\
.234\end{array}$ & $\begin{array}{l}.062 \\
.089\end{array}$ & $\begin{array}{l}.39 \\
.44\end{array}$ \\
\hline
\end{tabular}

* Values measured during clearance tests as in Table I. $\mathrm{L}_{\mathrm{Na}}=$ plasma $\mathrm{Na}$ (mEq. per ml.) times $\mathrm{C}_{\mathbf{y}}$ times 1.1 (the latter factor being used to adjust $C_{\mathbf{M}}$ to the rate of glomerular filtration); $U_{N a} V=$ urinary Na excretion; per cent $\mathrm{Na}$ reabsorbed was calculated as $\left(\mathrm{L}_{\mathrm{N}_{\mathrm{a}}}-\mathrm{U}_{\mathrm{Na}} \mathrm{V} / \mathrm{L}_{\mathrm{N}_{\mathrm{s}}}\right) 100$. $\mathrm{L}_{\mathrm{K}}$ and $\mathrm{U}_{\mathrm{K}} \mathrm{V}$ are, respectively, filtered load and urinary potassium excretion calculated as were the corresponding $\mathrm{Na}$ data. $\mathrm{C}_{K} / \mathrm{C}_{\mathbf{K}}$ expresses, roughly the proportion of filtered $\mathrm{K}$ appearing in the urine. 
TABLE IV

Proteinuria and urinary sediment counts *

\begin{tabular}{|c|c|c|c|c|c|}
\hline \multirow[b]{2}{*}{ Patient } & \multirow[b]{2}{*}{$\begin{array}{l}\text { Time of } \\
\text { study }\end{array}$} & \multirow[b]{2}{*}{$\begin{array}{c}\text { Proteinuria } \\
\mathrm{gm} . / 24 \mathrm{hr} .\end{array}$} & \multicolumn{3}{|c|}{ Sediment counts } \\
\hline & & & ${ }_{m}^{\text {Casts }}$ & $\underset{\text { Uions } / 1}{\mathrm{RBC}}$ & WBC \\
\hline \multirow[t]{2}{*}{1} & Preop. & 0.5 & 0 & 4.0 & 5.0 \\
\hline & $2 \mathrm{mo}$. & $\begin{array}{l}0.07 \\
0.08\end{array}$ & $\begin{array}{l}0.7 \\
1.8\end{array}$ & $\begin{array}{l}1.2 \\
2.0\end{array}$ & $\begin{array}{l}0.84 \\
0.5\end{array}$ \\
\hline \multirow[t]{2}{*}{2} & Preop. & 0.23 & 0.04 & 0.4 & 6.5 \\
\hline & 1 mo. & $\begin{array}{l}0.10 \\
0.13\end{array}$ & $\begin{array}{l}0 \\
0.25\end{array}$ & $\begin{array}{l}0.76 \\
1.4\end{array}$ & $\begin{array}{l}0.76 \\
3.0\end{array}$ \\
\hline \multirow[t]{2}{*}{3} & Preop. & 0.63 & 0.02 & 0 & 8.0 \\
\hline & $\begin{array}{l}2 \text { wk. } \\
3 \text { mo. }\end{array}$ & $\begin{array}{l}0.29 \\
0.25\end{array}$ & $\begin{array}{l}0.92 \\
0.12\end{array}$ & $\begin{array}{l}2.0 \\
0.52\end{array}$ & $\begin{array}{l}16.4 \\
10.6\end{array}$ \\
\hline
\end{tabular}

* Urinary protein excretion (Addis-Shevky method) in grams per 24 hours, and urinary sediment counts for casts, red and white blood cells, in millions per 12 hours preoperatively and postoperatively.

At the second observation, $\mathrm{L}_{\mathrm{Na}}$ had increased in all three, and the percentage of sodium reabsorbed was increased over the previous observation in patients 1 and 2 and decreased in patient 3 ; the ratio $C_{\mathbf{K}} / \mathrm{C}_{\mathbf{M}}$ was greatly decreased in the postoperative observations.

\section{Proteinuria and urinary sediment (Table IV)}

(a) Preoperative. There was slight proteinuria in each patient; cylindruria was absent or moderate; hematuria was present in patient 1 and increased numbers of white cells were present in all.

(b) Postoperative. Proteinuria diminished to normal ranges in patients 1 and 2 and to nearly normal in patient 3 . Patients 1 and 3 showed large numbers of casts; hematuria diminished in patient 1 and appeared at a low rate in patient 2 ; white cell counts returned to normal in patients 1 and 2 and persisted at a high rate in patient 3.

\section{DISCUSSION}

\section{Hemodynamics}

(a) Hypertension. Desoxycorticosterone (DC) and $\mathrm{NaCl}$ elicit hypertension and hypertensive vascular disease in rats $(7,8)$. It is assumed that the natural mineralocorticoid, aldosterone, would do the same, but this has not been the case in experiments of brief duration in rats (9), although it has been observed when aldosterone administra- tion is prolonged (10). Hypertension has been present in all reported cases of primary aldosteronism, although in patient 3 hypertension was never severe.

In patients 2 and 3 above and in the patient reported by Chalmers, Fitzgerald, James and Scarborough (11), hypertension did not remit, except transiently, after removal of the tumor, although it did in Conn's patient (1). Severe nephrosclerosis has been found in renal biopsy specimens from two patients $(11,12)$. Our patients 2 and 3 demonstrate functional evidence thereof. This nephrosclerosis may have contributed to persistence or recurrence of hypertension, perhaps by a mechanism similar to that of post-DCA hypertension in rats (13); this mechanism may be primarily renal, or may depend also on resetting of baroceptors (14). In either case, it must be assumed that aldosteronism was a primary cause of the hypertensive state and the subsequent nephrosclerosis. In patient 1 the long duration of the hypertension (26 years) and his positive family history might suggest that aldosteronism was a complication of essential hypertension. Paradoxically, this was the only patient whose hypertension was cured by removal of the tumor.

(b) Renal blood flow and filtration rate. Preoperative data from patients 1 and 2 are consistent with the presence of nephrosclerosis, leading to restriction of renal blood flow; the high filtration fraction of patient 2 suggested also defective renal extraction of PAH. This has been demonstrated in potassium-deficient patients (15); assuming a filtration fraction of 0.3 , the true renal plasma flow of patient 3 would be about $400 \mathrm{ml}$. per minute and $\mathrm{R}$ of the order of 11 . This resistance would be indicative of renal vasoconstriction and/or sclerosis.

Experience in the prolonged treatment of other forms of hypertensive disease indicated that renal resistance usually decreased with blood pressure in such a way that renal plasma flow and filtration rate did not change greatly, or that flow might even increase (16). Instead, resistance increased and filtration rate dropped, although in the last observations of patients 1 and 3 these tended to return towards normal. Two mechanisms come to mind: one is nephrosclerosis, and the other is a defect in the normal hemostasis of renal circu- 
lation which might be imposed by aldosterone deficiency. That nephrosclerosis was not the cause is indicated by the fact that it does not often have this effect in nephrosclerotic patients when blood pressure is decreased by chronic treatment. Hence, speculatively, it may be that aldosterone is somehow concerned with the "autonomy of the renal circulation" (17) and that operation created a more or less persistent state of hypoaldosteronism. This supposition is supported by the abnormal postoperative electrolyte status, in which there is acidosis and a tendency toward hyperkalemia, and by the profound effects of aldosterone on renal plasma flow and filtration rate in adrenalectomized animals (18) as compared with 11desoxycorticosterone.

\section{Water conservation}

Preoperatively, there was defective concentrating power during water deprivation, and also excretion of nearly isotonic urine during osmotic diuresis. These defects may be attributed either to structural loss or to the renal effects of potassium deficiency. Postoperatively, concentrating power was almost unchanged-suggesting that this defect was in fact partly structural-but water reabsorption during osmotic diuresis was restored to levels which, in relation to filtration rate, were approximately normal. This sequence indicates that the preoperative defect in water reabsorption during osmotic diuresis was a reversible defect imposed by potassium deficiency. There is an unexplained disparity between the pre- and postoperative maximum urinary specific gravities during concentration tests-these being nearly unchanged-and the large changes which took place in water reabsorptive function ( $\mathrm{T}^{\mathrm{c}} \mathrm{H}_{2} \mathrm{O}$ ) during osmotic diuresis.

This is another example of the dissociation between concentrating power measured after water deprivation and the $U / P$ osmolal ratios attainable during osmotic diuresis, such as we (unpublished observations) and others (19) have observed in patients with severe renal disease. Even normal subjects can be brought to excrete hypotonic urine by the sudden imposition of osmotic diuresis (20), and these several examples suggest to us the possibility that distal tubular fluid is hypotonic rather than isotonic, taking the view that excretion of hypotonic urine during osmotic diuresis represents the pouring out as urine of a substantially unmodified tubular fluid which is being swept past the more distal sites of water reabsorption in urine concentration. Very recently we have been informed (Prof. H. Wirz, personal communication, 1956) that there is direct evidence in favor of this concept; fluid obtained by puncture from distal convoluted tubules of anesthetized rats was found to be hypotonic to plasma at times when the ureteral urine was distinctly hypertonic.

\section{Acidification and aldosteronism}

Preoperatively, our patients excreted neutral or somewhat alkaline urine, even during concentration tests. The same was true of Conn's patient (1) and of the patient of Chalmers and his associates (11). This, like the defect in water reabsorption, might represent renal injury with a defect of the mechanism of urinary acidification, notably the renal carbonic anhydrase system. However, both this system and the ammonia mechanism, although perhaps defective, are still active in aldosteronism since the patient of Chalmers and his associates (11) was able to excrete ammonia-rich, acid urine when given ammonium chloride, and our patient 3 excreted excesses of both sodium and potassium when given acetazoleamide.

The problem lies in what mechanism it may be that will cause excretion of an alkaline, potassiumrich urine in the presence of hypokalemic alkalosis. Normally, the kidney excretes an acid urine in potassium depletion despite an extracellular alkalosis, whereas the urine of our alkalotic, hypokalemic patients was normally neutral or alkaline. It can be assumed that the determinant of urine $\mathrm{pH}$, of excretion of sodium and potassium, and of the ratio of basic to hydrogen ion in urine is the intracellular ionic concentration of potassium, or, as a functional reciprocal thereof, $\mathrm{CO}_{2}$ tension (21, 22). Aldosteronism would seem to violate this assumption, since the urine is alkaline while the cell is potassium deficient and the $\mathrm{CO}_{2}$ tension presumably increased. This paradox can be resolved if it is further assumed that intracellular potassium occurs in both bound $(K)$ and ionized $\left(\mathrm{K}^{+}\right)$forms $(23)$ and that the primary mechanism of the action of aldosterone is to shift the equi- 


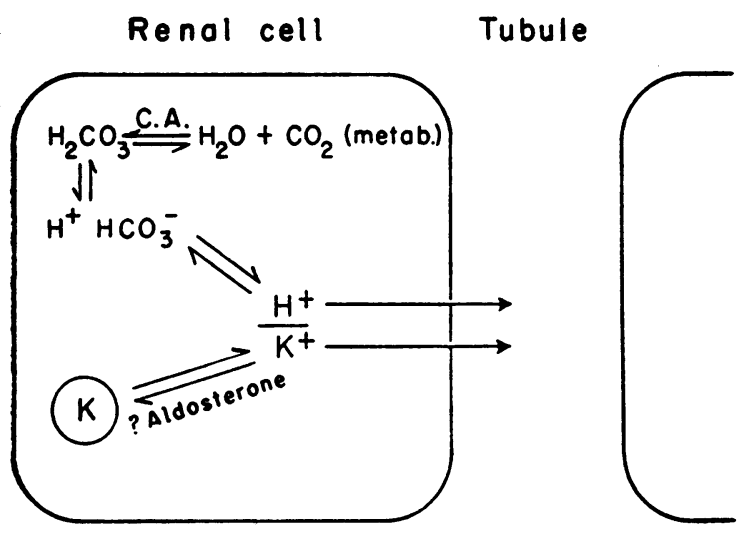

FIGURE 1

Schematic renal tubular cell indicating the relationship of hydrogen $\left(\mathrm{H}^{+}\right)$and potassium $\left(\mathrm{K}^{+}\right)$ions and the possibility that aldosterone may act by displacing the equilibrium between ionic $\left(\mathrm{K}^{+}\right)$and bound ( $\mathrm{K}$ in circle) potassium in the direction of increased ionization and excretion. C. A. denotes carbonic anhydrase.

librium $\mathrm{K} \rightleftarrows \mathrm{K}^{+}$in the direction of increased ionization. Such increased ionization of potassium would account for the concurrence of cellular potassium depletion with formation of potassium-rich alkaline urine (Figure 1). That the phenomenon is an expression of hormonal action and not of nonspecific renal damage is indicated by the prompt recovery of this function after operative removal of the tumors.

While aldosterone causes sodium retention as well as potassium excretion, our patients showed large losses of both sodium and potassium during osmotic diuresis. Postoperatively, the excess potassium excretion (ratio $C_{\mathbf{K}} / C_{\mathbf{M}}$ ) promptly diminished. In contrast, the preoperative relative sodium reabsorptions of these patients were not excessive, but, in our experience, low, and the postoperative changes were irregular. We have no explanation for this finding, except as we have observed similar large defects in sodium reabsorption during osmotic diuresis in patients with severe structural renal damage due to hypertensive disease. Conceivably, the sodium-retaining action of aldosterone might be observed even during osmotic diuresis in patients whose aldosteronism had not progressed, as in our cases, into a state of advanced potassium depletion and consequent renal tubular insufficiency, complicated also by nephrosclerosis. That the latter type of damage was present preoperatively and only slowly re- mitted postoperatively is indicated by the functional data (Tables II, III) and by the sediment counts (Table IV).

\section{SUMMARY AND CONCLUSIONS}

Preoperatively, 3 patients with primary aldosteronism showed decreased rates of renal plasma flow, but normal rates of glomerular filtration with increased renal vascular resistance in the second patient, and probably also in the third patient. Maximal nonprotein urinary specific gravity was disproportionately low in relation to other excretory renal functions, and, during mannitol osmotic diuresis, the osmolal $\mathrm{U} / \mathrm{P}$ ratios approximated unity with small net free water clearance in 2 patients. Serum potassium was low and $\mathrm{CO}_{2}$ combining power increased, but the urinary $\mathrm{pH}$ was consistently 7 or more. During osmotic diuresis, the patients excreted large amounts of sodium, and also showed high rates of relative potassium clearance. One patient responded to intravenous acetazoleamide by further decreasing sodium reabsorption and increasing potassium excretion. The urine contained excess protein and white cells.

Postoperatively, the renal plasma flow and filtration rate decreased in 2 of the 3 patients and only slowly recovered. Maximal specific gravity remained low, with some tendency to recover, but the capacity to reabsorb water during osmotic diuresis was promptly restored. The patients developed acidosis and normal or somewhat increased serum potassium concentrations and the urine became acid. The defect in sodium reabsorption persisted, but the rates of potassium clearance were greatly decreased. Proteinuria and pyuria subsided completely in 2 of the 3 patients.

The excess urinary excretion of potassium seems attributable to the direct action of aldosterone on renal tubular cells and may reflect the basic mechanism of this hormone's action. The polyuria and excretion of dilute urine are attributable to tubular potassium depletion and are only indirect effects of the hormone's actions. The observations during osmotic diuresis suggest that the fluid delivered from some more proximal site (distal convoluted tubules?) to a more distal region (collecting tubules?) for concentration by water reabsorption is hypotonic rather than isotonic. 
The postoperative course of renal function in association with low $\mathrm{CO}_{2}$ combining power and a tendency to hyperkalemia suggests that aldosterone may have a function in the maintenance of renal blood flow and glomerular filtration rate.

Clinically, aldosteronism should be considered a probable diagnosis in patients with hypertension of unknown origin who, in the presence of adequate excretory renal function, excrete urine which is persistently alkaline and who show also disproportionate loss of urinary concentrating power.

\section{REFERENCES}

1. Conn, J. W., Presidential address: Part I. Painting background. Part II. Primary aldosteronism, a new clinical syndrome. J. Lab. \& Clin. Med., 1955, $45,3$.

2. Hewlett, J. S., McCullagh, E. P., Farrell, G. L., Dustan, H. P., Poutasse, E., and Proudfit, W., Aldosterone-producing tumors of the adrenal gland. Report of three cases. Manuscript submitted for publication (J.A.M.A.).

3. Gomez, D. M., Evaluation of renal resistances, with special reference to changes in essential hypertension. J. Clin. Invest., 1951, 30, 1143.

4. Zak, G. A., Brun, C., and Smith, H. W., The mechanism of the formation of osmotically concentrated urine during the antidiuretic state. J. Clin. Invest., 1954, 33, 1064.

5. Page, I. H., and Corcoran, A. C., Arterial Hypertension; Its Diagnosis and Treatment. 2nd ed., Chicago, Year Book Publishers, 1949.

6. Van Slyke, D. D., and Hiller, A., Application of Sendroy's iodometric chloride titration to proteincontaining fluids. J. Biol. Chem., 1947, 167, 107.

7. Selye, H., Hall, C. E., and Rowley, E. M., Malignant hypertension produced by treatment with desoxycorticosterone acetate and sodium chloride. Canad. M. A. J., 1943, 49, 88.

8. Masson, G. M. C., Corcoran, A. C., and Page, I. H., Experimental vascular diseases due to desoxycorticosterone acetate and anterior pituitary extract. I. Comparison of functional changes. J. Lab. \&. Clin. Med., 1949, 34, 1416.

9. Gross, F., Loustalot, P., and Meier, R., Vergleichende Untersuchungen über die hypertensive Wirkung von Aldosteron und Desoxycorticosteron. Experientia, $1955,11,67$.
10. Kumar, D., Anderson, M. B., and Gornall, A. G., Postmortem study of rats made hypertensive by aldosterone. J. Endocrinol., 1956, 13, 16.

11. Chalmers, T. M., Fitzgerald, M. G., James, A. H., and Scarborough, H., Conn's syndrome with severe hypertension. Lancet, 1956, 1, 127.

12. Conn, J. W., and Louis, L. H., Primary aldosteronism, a new clinical entity. Ann. Int. Med., 1956, 44, 1.

13. Friedman, S. M., Friedman, C. L., and Nakashima, M., Sustained hypertension following the administration of desoxycorticosterone acetate. $J$. Exper. Med., 1951, 93, 361.

14. McCubbin, J. W., Green, J. H., and Page, I. H., Baroceptor function in chronic renal hypertension. Circ. Research, 1956, 4, 205.

15. Schwartz, W. B., and Relman, A. S., Metabolic and renal studies in chronic potassium depletion resulting from overuse of laxatives. J. Clin. Invest., 1953, 32, 258.

16. Corcoran, A. C., and Page, I. H., The kidney in hypertension. M. Clin. North America, 1955, July, 1027.

17. Smith, H. W., The Kidney : Structure and Function in Health and Disease. New York, Oxford Univ. Press, 1951.

18. Renzi, A. A., Renzi, M., Chart, J. J., and Gaunt, R., Effect of aldosterone and other steroids on renal functions and water intoxication. J. Clin. Endocrinol. \& Metab., 1955, 15, 853.

19. Baldwin, D. S., Berman, H. J., Heinemann, H. O., and Smith, H. W., The elaboration of osmotically concentrated urine in renal disease. J. Clin. Invest., 1955, 34, 800 .

20. de Wardener, H. E., and del Greco, F., The influence of solute excretion rate on the production of a hypotonic urine in man. Clin. Sc., 1955, 14, 715.

21. Berliner, R. W., Kennedy, T. J., Jr., and Orloff, J., Relationship between acidification of the urine and potassium metabolism. Effect of carbonic anhydrase inhibition on potassium excretion. Am. J. Med., 1951, 11, 274.

22. Roberts, K. E., Randall, H. T., Sanders, H. L., and Hood, M., Effects of potassium on renal tubular reabsorption of bicarbonate. J. Clin. Invest., 1955, 34,666 .

23. Squires, R. D., Crosley, A. P., Jr., and Elkinton, J. R., The distribution of body fluids in congestive heart failure. III. Exchanges in patients during diuresis. Circulation, 1951, 4, 868. 